\title{
ANALISIS FAKTOR-FAKTOR YANG MEMPENGARUHI MINAT BELI KONSUMEN PADA SITUS JUAL-BELI ONLINE
}

\author{
I Gede Andri Setiawan \\ gedeandri18@gmail.com \\ Universitas Ahmad Dahlan \\ Sukardi \\ sukardi_feuad@yahoo.com \\ Universitas Ahmad Dahlan
}

\begin{abstract}
ABSTRAK
The purpose of this study were to analyze (1) the influence of trust of the purchase interest of online shop consumers, (2) the influence of risk perception of the purchase interest of online shop consumers, (3) the influence of use fulness perception of the purchase interest of online shop consumers, (4) the influence of price perception of the purchase interest of online shop consumers. The populations in this research are student of Ahmad Dahlah University Yogyakarta Campus One. The method sample is purposif sampling with the number of sample as much as 100 respondents from three Faculty that is, Economy Faculty, Psycology Faculty, and FTDI. Collecting data using questionnaires that was done validity test and realibity test. This research was done by using multiple linear regression data analysis. The results of this study indicate that (1) the trust is not significant influence on consumer purchase interest of the sites online shop, this is evidenced by the significant value is bigger than the probability alpha value of 0.05 $(0,206>0.05)$, and the regression coefficient has a positive value of $0.062 ;(2)$ the trust is not significant influence on consumer purchase interest of the sites online shop, this is evidenced by the significant value is bigger than the probability alpha value of $0.05(0$, $0,234>0.05$ ), and the regression coefficient has a positive value of 0.057 ; (3) the usefulness perception is significant influence on consumer purchase interest of the sites online shop, this is evidenced by the significant value is smaller than the probability alpha value of $0.05(0.000<0.05)$, and the regression coefficients has a positive value of 0.456 ; (4) the price perception is not significant influence on consumer purchase interest of the sites online shop, this is evidenced by the significant value is bigger than the probability alpha value of $0.05(0.066>0.05)$, and the regression coefficient has a positive value of 0.111 ; and (5) trust, risk perception, usefulness perception and price perception together have an effect on consumer purchase interest of the sites online shop, this is evidenced by the significant value is smaller than the probability alpha value of $0.05(0.000<0.05)$. The $\mathrm{R} 2$ test results in this study was obtained $\mathrm{R} 2$ value of 0.413. This shows that purchase interest is influenced by trust, risk perception, use perception, and price perception by $41.3 \%$, while the remaining $58.7 \%$ is influenced by other factors not observed by the researcher or considered fixed.
\end{abstract}

Keywords: Trust; Risk Perception; Usefulness Perception; Price Perception; Purchase Interest. 


\section{PENDAHULUAN}

Perkembangan teknologi informasi dewasa ini telah berkembang sangat pesat termasuk internet. Hal ini tidak aneh mengingat jumlah pengguna internet yang terus berkembang pesat sehingga dapat menjadi sebuah pasar yang potensial. Pemasaran elektronik merupakan upaya perusahaan untuk memberikan informasi, melakukan komunikasi, mempromosikan, dan menjual produk dan layanan melalui internet. Saluran elektronik merupakan saluran terbaru dari pemasaran langsung (direct marketing), yang menggambarkan satu varietas luas dari perangkat lunak atau sistem komputer elektronik. Pengiriman pesanan pembelian kepada pemasok melalui electronic data interchange (EDI), penggunaan fax dan e-mail untuk melakukan transaksi, penggunaan ATM, kartu kredit, e-banking untuk memudahkan pembayaran, mendapatkan uang tunai secara digital, dan penggunaan internet dan layanan online (Yusnidar, 2014).

Perkembangan ilmu dan teknologi pada dasarnya bertujuan untuk mencapai serta memenuhi aspirasi dan kebutuhan manusia dalam memanfaatkan sumber daya manusia yang tersedia secara efisien, misalnya dunia industri dan teknologi dewasa ini. Perkembangan teknologi saat ini telah berhasil menggabungkan proses informasi dan komunikasi. Dengan kehadiran internet perusahaan bahkan tidak perlu mengikuti pameran dagang untuk memperlihatkan barang-barang suatu perusahaan kepada pembeli dan distributor luar negeri (Kotler, 2008).

\section{E-commerce (Perdagangan}

elektronik) merupakan sebuah sistem pemasaran yang merupakan salah satu saluran dari pemasaran langsung. Belanja online atau disebut juga belanja daring merupakan kegiatan jual-beli yang memungkinkan konsumen untuk langsung membeli produk dari penjual melalui internet menggunakan sebuah situs web browser (Oktavianingrum, 2015). Hal tersebut sangat direspon positif oleh para pelaku usaha, distributor maupun konsumen dalam bertransaksi untuk mengurangi biaya serta untuk menghemat waktu, sebab belanja atau transaksi online dapat dilakukan dimana saja dan kapan saja.

Media yang banyak digunakan oleh pelaku bisnis jual-beli online adalah berupa situs berbasis website. Berdasarkan survey yang dlakukan salah satu situs penyedia jasa traffic web. Alexa.com (2016) situs jual-beli online yang ada di Indonesia yang banyak dikunjungi oleh pengguna internet adalah Facebook.com, Kaskus.com, Bukalapak.com, Tokopedia.com, Lazada.com, dan Olx.com.

Riset yang dilakukan oleh Asosiasi Penyelenggara Jasa Internet Indonesia (APJII) bekerjasama dengan Pusat Kajian Komunikasi (PusKaKom) Universitas Indonesia (UI) dalam rangka untuk menemukan jawaban pertumbuhan pengguna internet. Dari Riset APJII (2015) tersebut mengungkapkan bahwa jumlah pengguna internet di Indonesia hingga akhir tahun 2014 mencapai 88 juta orang dengan jumlah penduduk sebanyak 252,4 juta orang dan terpenetrasi sebanyak 34,9\%. Dilihat dari APJII (2015), persentase pengguna internet di Indonesia hingga akhir 2014 berdasarkan usia dapat dibagi dalam beberapa kategori usia yaitu, usia 56-65 tahun (0.2\%), usia 46-55 tahun (2.4\%), usia 36-45 tahun (14.6\%), usia 26-35 tahun (33.8\%), dan usia 18-25 tahun (49.0\%). Sedangkan persentase pengguna internet berdasarkan aktivitas dapat di golongkan kedalam beberapa kategori sebagai berikut, mahasiswa (18\%), ibu rumah tangga (16\%), tidak bekerja (6\%), pelajar (SD/SMP/SMA sederajat) (5\%), dan bekerja/wiraswasta $(55 \%)$. Sehingga dari data tersebut dapat dilihat bahwa peluanguntuk memasarkan produk mengguanakan media internet sangat potensial untuk dilakukan.

Di dalam dunia internet penggunanya berasal dari berbagai latar 
belakang yang berbeda baik dari segi usia, pendidikan, aktivitas maupun pekerjaan. Dari kategori-kategori tersebut dapat dijadikan sebagai bahan untuk menentukan segmen pasar atau konsumen yang ditarget. Konsumen merupakan salah satu faktor utama pendukung agar sebuah bisnis dapat berjalan dengan baik, sehingga para manajer dituntut agar bisa membangun kepercayaan dari konsumen.

Perilaku membeli yang tidak sesuai dengan kebutuhan dilakukan semata-mata demi kesenangan, sehingga menyebabkan seseorang menjadi boros yang dikenal dengan istilah prilaku konsumtif. Konsumtivisme merupakan paham untuk hidup secara konsumtif, sehingga orang yang konsumtif dapat dikatakan tidak lagi mempertimbangkan fungsi atau kegunaan ketika membeli barang akan tetapi menimbangkan prestise yang melekat pada barang tersebut. Konsumsi merupakan cerminan aksi yang tampak, sedangkan konsumerisme lebih terkait dengan motivasi yang terkandung di dalamnya. Secara umum batasan konsumtivisme yaitu kecenderungan manusia untuk menggunakan konsumsi tanpa batas, dan manusia lebih mementingkan faktor keinginan daripada kebutuhan.

Kepercayaan konsumen adalah kekuatan pengetahuan yang dimiliki oleh konsumen dan semua kesimpulan yang dibuat konsumen bahwa produk mempunyai objek, atribut, dan manfaat (Sangadji, 2013). Objek dapat berupa produk, orang, perusahaan, dan segala sesuatu dimana seseorang memiliki kepercayaan dan sikap. Perubahan gaya hidup yang serba praktis juga mempengaruhi pola berbelanja masyarakat. Pembelian secara online adalah salah satu kecenderungan seseorang untuk melakukan pembelian online melalui internet. Kecenderungan yang dimaksud adalah pengalaman melalui proses pembelian dari tahap pencarian (search stage) sampai pada niat (intention) untuk melakukan pembelian online bahkan pada proses finalnya akan terjadi tahap keputusan pembelian.

Faktor lain yang menjadi pertimbangan para konsumen online ketika hendak melakukan belanja online adalah faktor resiko. Ini disebabkan karena di dalam proses transaksi jual beli online pembeli tidak bertemu secara langsung dengan penjual. Dari proses jual beli tersebut ada rasa kehawatiran akan kehilangan uang, ada rasa hawatir akan waktu pengiriman, dan ada juga rasa hawatir akan ketidak sesuaian produk yang diterima.

Informasi yang di berikan oleh pedagang kepada konsumen sangat penting sebab jika seseorang telah menilai jika sistem informasi yang digunakan bermanfaat maka dia akan menggunakannya. Sebaliknya jika seseorang meyakini bahwa sistem informasi yang digunakan kurang bermanfaat maka dia tidak akan menggunakannya.

Konsumen telah pandai dalam hal menentukan pilihan produk yang akan di beli, salah satu faktor utama yang pertama kali menjadi pertimbangan konsumen ketika akan membeli suatu produk adalah harga. Harga merupakan salah satu unsur bauran pemasaran yang menghasilkan pendapatan; unsur-unsur lainnya menghasilkan biaya, harga barangkali adalah unsur program pemasaran yang paling mudah disesuaikan; ciri-ciri produk, saluran, bahkan promosi membutuhkan lebih banyak waktu, harga juga mengkomunikasikan posisi nilai yang dimaksudkan perusahaan tersebut kepada pasar tentang produk mereka atau mereknya (Kotler, 2008). Sehingga para pedagang online mulai menerapkan strategi harga untuk menarik minat konsumen selain untuk mengkomunikasikan produk yang akan ditawarkan kepada konsumen, harga juga dapat digunakan untuk membangun citra perusahaan.

Mahasiswa adalah konsumen yang paling potensial sebagai sasaran pasar 
online. Yang menyebabkan mahasiswa sebagai pasar yang potensial adalah karena sifat kritis keaktifan mahasiswa dalam mencari dan menentukan tempat untuk memperoleh seluruh kebutuhan mereka untuk menunjang gaya hidup mereka yang sudah mulai kekinian. Disamping itu juga mahasiswa sangat aktif di dalam sosial media, sehingga mereka dapat dengan mudah untuk mengakses segala informasi yang tersedia. Kebutuhan mahasiswa yang semakin kompleks juga menjadi salah satu faktor yang mendorong mahasiswa lebih kreatif dan selektif dalam berbelanja.

Dengan adanya e-commerce mahasiswa kini dapat dengan mudah mengakses informasi yang dibutuhkan. Dengan mengakses situs $e$-commerce yang mahasiswa inginkan, mahasiswa dapat memilih produk sesuai dengan keinginan dengan berbagai spesifikasi produk dan harga yang beragam. Selain sebagai target pasar yang potensial mahasiswa juga dapat berperan sebagai agen-agen yang dapat mengedukasi masyarakat tentang cara-cara untuk mengakses situs $e$ commerce. Sehingga setelah masyarakat teredukasi e-commerce akan menjadi tren pasar yang baru.

Berdasarkan fenomena yang terjadi, peneliti ingin mengetahui faktor apa saja yang mepengaruhi minat beli konsumen pada situs jual-beli online.Penelitian ini mengacu pada penelitian sebelumnya yaitu penelitian Yusnidar (2014), Nusarika (2015), Trisnawati, (2012). Yusnidar (2014) melakukan penelitian tentang pengaruh kepercayaan dan persepsi resiko terhadap minat beli dan keputusan pembelian produk fashion secara online di kota Pekanbaru, penelitian tersebut menunjukkan bahwa faktor persepsi resiko dan kepercayan memiliki pengaruh terhadap minat beli konsumen online. Nusarika (2015) melakukan penelitian tentang pengaruh persepsi harga, kepercayaan, dan orientasi belanja terhadap niat beli secara online (studi pada produk fashion online di kota Denpasar), penelitian tersebut menunjukkan bahwa faktor persepsi harga, kepercayaan dan orientasi belanja berpengaruh positif dan signifikan terhadap niat beli produk fashion online di Kota Denpasar. Sedangkan Trisnawati, (2012) melakukan penelitian tentang analisis faktor-faktor kunci dari niat pembelian kembali secara online (studi kasus pada konsumen fesh shop), menunjukkan bahwa ada faktor Perceived ease of use, Perceived usefulness, Confirmation, Satisfaction, Perceived ease of use, Trust, Perceived enjoyment, dan Privacy yang berpengaruh positif dan signifikan terhadap niat pembelian kembali secara online.

Tujuan dari penelitian ini di antaranya: 1) untuk menguji Kepercayaan memiliki pengaruh secara parsial terhadap minat beli konsumen online pada mahasiswa UAD kampus satu, 2) untuk menguji Persepsi Resiko memiliki pengaruh secara parsial terhadap minat beli konsumen online pada mahasiswa UAD kampus satu, 3) untuk menguji Persepsi Manfaat memiliki pengaruh secara parsial terhadap minat beli konsumen online pada mahasiswa UAD kampus satu, 4) untuk menguji Persepsi Harga memiliki pengaruh secara parsial terhadap minat beli konsumen online pada mahasiswa UAD kampus satu dan 5) untuk menguji Kepercayaan, Persepsi Resiko, Persepsi Manfaat, dan Persepsi Harga memiliki pengaruh secara simultan terhadap minat beli konsumen online pada mahasiswa UAD kampus satu.

\section{REVIEW LITERATUR DAN HIPOTESIS}

\section{Landasan Teori}

\section{E-Commerce}

E-commerce merupakan sebuah sistem pemasaran yang merupakan salah satu saluran dari pemasaran langsung. E-commerce (perdagangan elektronik) berarti perusahaan atau situs menawarkan untuk melakukan transaksi atau memudahkan penjualan 
produk dan jasa secara online (Kotler, 2008).

2. Minat Beli

Menurut Kotler (2005) dikutip dalam Rachman (2014) minat beli konsumen adalah sesuatu yang timbul setelah menerima rangsangan dari produk yang dilihatnya, dari sana timbul ketertarikan untuk mencoba produk tersebut sampai akhirnya timbul keinginan untuk membeli agar dapat memilikinya.

3. Kepercayaan Konsumen

$$
\text { Menurut Mowen }
$$

kepercayaan konsumen (consumer beliefs) adalah semua pengetahuan yang dimiliki oleh konsumen dan semua kesimpulan yang dibuat konsumen tentang objek, atribut, dan manfaatnya.

\section{Persepsi Risiko}

Menurut Bhatnagar, et. al., (2000) dikutip dalam Oktavianingrum (2015) persepsi akan risiko merupakan anggapan risiko yang menghadirkan penilaian seseorang akan adanya kemungkinan atas hasil positif ataupun negatif dari suatu transaksi atau situasi, serta sebuah bentuk multidimensional yang terdiri dari risiko produk dan keuangan dalam belanja daring (belanja online).

\section{Persepsi Manfaat}

Menurut Wen et. al., (2011) dikutip dalam Trisnawati (2012) mendefinisikan perceived usefulness sebagai penilaian konsumen terhadap manfaat informasi produk yang dibutuhkan dan dirasakan pada saat berbelanja di toko berbasis web. Dari teori tersebut dapat disimpulkan bahwa jika seseorang telah menilai jika sistem informasi yang digunakan bermanfaat maka dia akan menggunakannya. Sebaliknya jika seseorang meyakini bahwa sistem informasi yang digunakan kurang bermanfaat maka dia tidak akan menggunakannya.

6. Persepsi Harga

Menurut Swastha (2008) harga adalah jumlah uang (ditambah beberapa produk kalau mungkin) yang dibutuhkan untuk mendapatkan sejumlah kombinasi dari produk dan pelayananya. Dari sudut pandang konsumen, biasanya harga didefinisikan sebagai yang harus diberikan konsumen untuk membeli barang atau jasa. Biasanya riset memandang harga hanya dalam konteks jumlah dolar yang diminta untuk penukar barang atau jasa (Peter, 2014).

\section{Penelitian Terdahulu}

Penelitian yang dilakukan Yusnidar (2014) tentang Pengaruh Kepercayaan Dan Persepsi Resiko Terhadap Minat Beli Dan Keputusan Pembelian Produk Fashion Secara Online di Kota Pekanbaru menunjukkan bahwa faktor kepercayaan dan persepsi resiko memiliki pengaruh positif dan signifikan terhadap minat beli dan keputusan pembelian produk fashion secara online di kota Pekanbaru. Dari penelitian tersebut dapat diartikan bahwa variabel kepercayaan dan Persepsi Resiko dapat dijadikan salah satu variabel independen untuk diuji kembali, karena besar peran variabel tersebut terhadap minat pembelian online.

Nusarika (2015) melakukan sebuah penelitian tentang Pengaruh Persepsi Harga, Kepercayaan, dan Orientasi Belanja Terhadap Niat Beli Secara Online (Studi pada Produk Fashion Online di Kota Denpasar). Penelitian tersebut menunjukkan bahwa faktor Pesepsi harga, kepercayaan dan orientasi belanja berpengaruh positif dan signifikan terhadap niat beli produk fashion online di Kota Denpasar. Ini berarti semakin meningkat persepsi harga, kepercayaan dan orientasi belanja maka semakin meningkat juga niat beli konsumen terhadap produk fashion online di Kota 
Denpasar. Dapat diartikan bahwa disini variabel persepsi Harga, kepercayaan, dan orientasi belanja dapat dijadikan salah satu variabel independen untuk diuji kembali, karena besar peran variabel tersebut terhadap Minat pembelian online.

Pada penelitian Trisnawati (2012) tentang Analisis Faktor Faktor Kunci Dari Niat Pembelian Kembali Secara Online (Study Kasus Pada Konsumen Fesh Shop) menunjukkan bahwa faktor Perceived ease of use, Perceived usefulness, Confirmation, Satisfaction, Perceived ease of use, Trust, Perceived enjoyment, dan Privacy berpengaruh positif dan signifikan terhadap niat pembelian kembali secara online. Dapat diartikan bahwa disinivariabel Perceived ease of use, Perceived usefulness, Confirmation, Satisfaction, Perceived ease of use, Trust, Perceived enjoyment, Privacydapat dijadikan salah satu variabel independen, karena besar peran variabel tersebut terhadap Minat pembelian online untuk diuji kembali.

\section{Hipotesis}

H1: Kepercayaan berpengaruh terhadap minat beli konsumen online pada mahasiswa UAD kampus satu.

H2: Persepsi Resiko berpengaruh terhadap minat beli konsumen online pada mahasiswa UAD kampus satu.

H3: Persepsi Manfaat berpengaruh terhadap minat beli konsumen online pada mahasiswa UAD kampus satu.

H4: Persepsi Harga berpengaruh terhadap minat beli konsumen online pada mahasiswa UAD kampus satu.

H5: Kepercayaan, Persepsi Resiko, Persepsi Manfaat, dan Persepsi Harga, berpengaruh terhadap minat beli konsumen online pada mahasiswa UAD kampus satu secara bersama-sama.

\section{METODE PENELITIAN}

\section{Populasi dan Sampel}

Populasi adalah kumpulan dari semua anggota yang diteliti (Algifari, 2013). Menurut Sugiyono (2010), populasi adalah wilayah generalisasi yang terdiri atas obyek/subyek yang mempunyai kualitas dan karakteristik tertentu yang ditetapkan oleh peneliti untuk dipelajari dan kemudian ditarik kesimpulan.

Dari teori-teori di atas dapat ditarik kesimpulan bahwa populasi yaitu kumpulan dari semua anggota atau wilayah generalisasi dari obyek yang memiliki kualitas atau karakteristik tertentu untuk dipelajari peneliti dan kemudian ditarik kesimpulan. Sehingga untuk memperoleh hasil penelitian yang diharapakan, pada penelitian ini peneliti menggunakan seluruh mahasiswa Universitas Ahmad Dahlan Yogyakarta kampus satu yang pernah menggunakan media elektronik untuk melakukan pencarian (situs jual-beli online) sebagai obyek penelitian.

Sampel adalah kumpulan sebagian anggota dari obyek yang diteliti (Algifari, 2013). Menurut Sugiyono (2010), sampel adalah bagian dari jumlah dan karakteristik yang dimiliki oleh populasi tersebut. Bila populasi besar, dan peneliti tidak mungkin mempelajari semua yang ada pada populasi, misalnya karena keterbatasan dana, tenaga dan waktu, maka peneliti dapat menggunakan sampel yang diambil dari populasi itu. Apa yang dipelajari dari sampel itu, kesimpulanya akan dapat diberlakukan untuk populasi. Untuk itu sampel yang diambil dari populasi harus benar-benar representative (mewakili).

Dari teori-teori di atas dapat disimpulkan bahwa sampel adalah sebagian dari jumlah anggota atau karakteristik dari obyek atau populasi yang diteliti. Sampel dalam penelitian ini adalah sebagian mahasiswa Universitas 
Ahmad Dahlan Yogyakarta kampus satu yang pernah mengunakan media elektronik untuk melakukan pencarian (situs jual-beli online) meliputi Fakultas Ekonomi, Fakultas Psikologi, dan FTDI.

\section{Definisi Operasional}

1. Variabel Independen

Variabel ini sering disebut sebagai variabel stimulus, prediktor, antecedent. Dalam bahasa Indonesia sering disebut sebagai variabel bebas. Variabel bebas adalah merupakan variabel yang mempengaruhi atau yang menjadi sebab perubahannya atau timbulnya variabel dependen (terikat). Dalam SEM (Structural Equition Modeling / Pemodalan Persamaan Struktural), variabel independen disebut sebagai variabel eksogen (Sugiyono, 2010). Variabel independen dalam penelitian ini yaitu Kepercayaan, Pesepsi Resiko, Persepsi Manfaat, dan Persepsi Harga.

2. Variabel Dependen

Sering disebut sebagai variabel output, kriteria, konsekuen. Dalam bahasa Indonesia sering disebut sebagai variabel terikat. Variabel terikat merupakan variabel yang dipengaruhi atau yang menjadi akibat, karena adanya variabel bebas. Dalam SEM (Structural Equition Modeling / Pemodalan Persamaan Struktural, variabel dependen disebut sebagai variabel indogen (Sugiyono, 2010). Variabel dependen dalam penelitian ini yaitu Minat Beli.

\section{Uji Instrumen}

1. Uji Validitas

Validitas merupakan derajat ketepatan antara data yang sesungguhnya terjadi pada obyek penelitian dengan data yang dapat dilaporkan oleh peneliti. Dengan demikian data data yang valid adalah data "yang tidak berbeda" antara data yang dilaporkan oleh peneliti dengan data yang sesungguhnya terjadi pada obyek penelitian (Sugiyono, 2008). Uji validitas digunakan untuk mengukur sah atau tidaknya suatu kuesioner (Adhilla, 2013). Apabila $r$ hitung lebih besar dari $r$ tabel dan bernilai positif, maka pernyataan atau indikator tersebut valid (Oktavianingrum, 2015).

\section{Uji Reliabilitas}

Reliabilitas sebenarnya adalah alat untuk mengukur suatu kuesioner yang merupakan indikator dari variabel atau konstruk (Adhilla, 2013). Dalam pandangan positivistik (kuantitatif), suatu data dinyatakan reliabel apabila dua atau lebih peneliti dalam objek yang sama menghasilkan data yang sama, atau peneliti sama dalam waktu berbeda menghasilkan data yang sama, atau sekelompok data bila dipecah menjadi dua menunjukkan data yang tidak berbeda (Sugiyono, 2008).

Penggunaan koefisien alfa menurut Sekaran (2000) dikutip dalam Rianto (2003):

a. Koefisien alfa kurang dari 0,6 dianggap mempunyai reliabilitas yang buruk.

b. Koefisien alfa di antara 0,6 sampai 0,8 dianggap reliabilitas yang dapat diterima.

\section{Teknik Analisis Data}

1. Analisis Regresi Berganda

$$
\mathbf{Y}=\mathbf{a}+\mathbf{b}_{1} \mathbf{X}_{1}+\mathbf{b}_{2} \mathbf{X}_{2}+\mathbf{b}_{3} \mathbf{X}_{3}+\mathbf{b}_{3} \mathbf{X}_{3}+\mathbf{b}_{4} \mathbf{X}_{4}+e
$$

Dimana:

$\mathrm{Y}=$ Minat Beli

$\mathrm{a}=$ Konstanta

$\mathrm{b}=$ Koefisien Regresi

X1 = Persepsi Kepercayaan

$\mathrm{X} 2=$ Pesepsi Resiko

$\mathrm{X} 3=$ Persepsi

X4 = Persepsi Harga

$\mathrm{e}=$ Error 


\section{Uji Hipotesis}

1. Uji Parsial (Uji T)

Uji t digunakan untuk mengetahu perbedaan nilai dari rata-rata populasi dengan nilai rata-rata sampel yang digunakan sebagai pembanding (Adhilla, 2013).

Jika nilai signifikan $>$ alpha $5 \%$ maka kesimpulannya menerima $\mathrm{H} 0$.

Jika nilai signifikan < alpha 5\% maka kesimpulannya menerima $\mathrm{Ha}$.

\section{Uji Simultan (Uji F)}

Uji $\mathrm{F}$ atau ANOVA (analysis of fariance) merupakan salah satu uji komparatif yang digunakan untuk menguji perbedaan rata-rata data pada lebih dari dua kelompok (Adhilla, 2013).

\section{Uji Koefisien Determinasi}

Koefisien determinasi dapat digunakan sebagai petunjuk untuk mengetahui sejauh mana variabel independen dapat menjelaskan variasi variabel dependen. Besarnya koefisien determinasi adalah kuadrat dari koefisien korelasi. Misalnya suatu persamaan regresi mempunyai koefisien korelasi (r)-nya adalah 0,9 atau 90\% maka besarnya koefisien determinasi (r2) persamaan regresi tersebut adalah 0,81 atau $81 \%$, sedangkan sisanya $19 \%$ dijelaskan (dipengaruhi) oleh variabel lain diluar persamaan regresi (model) tersebut (Algifari, 2013).

\section{HASIL PENELITIAN DAN PEMBAHASAN}

\section{Hasil Analisis Responden}

Klasifikasi Responden Berdasarkan Fakultas

\begin{tabular}{|c|c|c|}
\hline \multirow{2}{*}{ Fakultas } & \multicolumn{2}{|c|}{ Jumlah Responden } \\
\cline { 2 - 3 } & Frekuensi & Prosentase \\
\hline Ekonomi & 53 & $53 \%$ \\
\hline Psikologi & 30 & $30 \%$ \\
\hline FTDI & 17 & $17 \%$ \\
\hline Jumlah & 100 & $100 \%$ \\
\hline
\end{tabular}

Tabel di atas menunjukkan bahwa dari 100 responden, berdasarkan Fakultas Ekonomi 53 orang atau 53\%, Psikologi 30 orang atau $30 \%$, FTDI 17 orang atau $17 \%$.

Klasifikasi Responden Berdasarkan Jenis Kelamin

\begin{tabular}{|c|c|c|}
\hline \multirow{2}{*}{ Jenis Kelamin } & \multicolumn{2}{|c|}{ Jumlah Responden } \\
\cline { 2 - 3 } & Frekuensi & Prosentase \\
\hline Laki-laki & 59 & $59 \%$ \\
\hline Perempuan & 41 & $41 \%$ \\
\hline Jumlah & 100 & $100 \%$ \\
\hline
\end{tabular}

Tabel di atas menunjukkan bahwa dari 100 responden, berdasarkan jenis kelamin didominasi oleh laki-laki yaitu sebanyak 59 orang atau 59\%, sedangkan 41 orang atau $41 \%$ adalah perempuan.

Klasifikasi Responden Berdasarkan Semester

\begin{tabular}{|c|c|c|}
\hline \multirow{2}{*}{ Semester } & \multicolumn{2}{|c|}{ Jumlah Responden } \\
\cline { 2 - 3 } & Frekuensi & Prosentase \\
\hline 1 & 17 & $17 \%$ \\
\hline 3 & 13 & $13 \%$ \\
\hline 5 & 15 & $15 \%$ \\
\hline 7 & 50 & $50 \%$ \\
\hline 9 & 5 & $5 \%$ \\
\hline Jumlah & 100 & $100 \%$ \\
\hline
\end{tabular}

Tabel di atas menunjukkan bahwa dari 100 responden, berdasarkan semester 1 terdapat 17 orang atau $17 \%$, semester 3 terdapat 13 orang atau $13 \%$, semester 5 terdapat 15 orang atau $15 \%$, semester 7 terdapat 50 orang atau $50 \%$, semester 9 terdapat 5 orang atau $5 \%$. 
Klasifikasi Responden Berdasarkan Minat Beli

\begin{tabular}{|c|c|c|c|}
\hline Fakultas & Jumlah Responden & Total Skor & Nilai Rata-Rata \\
\hline Ekonomi & 53 & 693 & 13,1 \\
\hline Psikologi & 30 & 355 & 11,8 \\
\hline FTDI & 17 & 213 & 12,5 \\
\hline
\end{tabular}

\section{Hasil Penelitian}

\section{Hasil Uji Validitas}

Hasil Uji Validitas Kepercayaan, Persepsi Resiko, Persepsi Manfaat, Persepsi Harga, dan Minat Beli

\begin{tabular}{|c|c|c|c|c|c|}
\hline No & Variabel & Item & Thit & rtabel & $\begin{array}{c}\text { Keteranga } \\
n\end{array}$ \\
\hline \multirow{9}{*}{1} & \multirow{9}{*}{ Kepercayaan $=k p c$} & 1 & 0.554 & 0.3610 & Valid \\
\hline & & 2 & 0.555 & 0.3610 & Valid \\
\hline & & 3 & 0.700 & 0.3610 & Valid \\
\hline & & 4 & 0.715 & 0.3610 & Valid \\
\hline & & 5 & 0.750 & 0.3610 & Valid \\
\hline & & 6 & 0.771 & 0.3610 & Valid \\
\hline & & 7 & 0.565 & 0.3610 & Valid \\
\hline & & 8 & 0.619 & 0.3610 & Valid \\
\hline & & 9 & 0.530 & 0.3610 & Valid \\
\hline \multirow{8}{*}{2} & \multirow{8}{*}{$\begin{array}{c}\text { Persepsi } \\
\text { Resiko=rsk }\end{array}$} & 1 & 0.732 & 0.3610 & Valid \\
\hline & & 2 & 0.631 & 0.3610 & Valid \\
\hline & & 3 & 0.471 & 0.3610 & Valid \\
\hline & & 4 & 0.668 & 0.3610 & Valid \\
\hline & & 5 & 0.761 & 0.3610 & Valid \\
\hline & & 6 & 0.751 & 0.3610 & Valid \\
\hline & & 7 & 0.717 & 0.3610 & Valid \\
\hline & & 8 & 0.631 & 0.3610 & Valid \\
\hline \multirow{4}{*}{3} & \multirow{4}{*}{$\begin{array}{c}\text { Persepsi } \\
\text { Manfaat }=m n f\end{array}$} & 1 & 0.745 & 0.3610 & Valid \\
\hline & & 2 & 0.781 & 0.3610 & Valid \\
\hline & & 3 & 0.749 & 0.3610 & Valid \\
\hline & & 4 & 0.799 & 0.3610 & Valid \\
\hline \multirow{8}{*}{4} & \multirow{8}{*}{$\begin{array}{c}\text { Persepsi } \\
\text { Harga }=h r g\end{array}$} & 1 & 0.772 & 0.3610 & Valid \\
\hline & & 2 & 0.481 & 0.3610 & Valid \\
\hline & & 3 & 0.725 & 0.3610 & Valid \\
\hline & & 4 & 0.804 & 0.3610 & Valid \\
\hline & & 5 & 0.706 & 0.3610 & Valid \\
\hline & & 6 & 0.594 & 0.3610 & Valid \\
\hline & & 7 & 0.768 & 0.3610 & Valid \\
\hline & & 8 & 0.718 & 0.3610 & Valid \\
\hline \multirow{4}{*}{5} & \multirow{4}{*}{ Minat Beli $=m n t b l$} & 1 & 0.745 & 0.3610 & Valid \\
\hline & & 2 & 0.781 & 0.3610 & Valid \\
\hline & & 3 & 0.749 & 0.3610 & Valid \\
\hline & & 4 & 0.799 & 0.3610 & Valid \\
\hline
\end{tabular}

Dari hasil uji validitas di atas diketahui bahwa hasil dari faktor kepercayaan, Persepsi resiko, Persepsi Manfaat, Persepsi Harga, dan Minat beli diperoleh nilai $\mathrm{r}$ hit lebih besar dari pada nilai $r$ tab ( $r$ hit $>0.3610$ ), sehingga dapat disimpulkan bahwa hasil uji validitas tersebut valid.

2. Hasil Uji Reliabilitas

Hasil Uji Reliabilitas Minat Beli Pada Situs Jual Beli Online

\begin{tabular}{|l|c|c|c|}
\hline \multicolumn{1}{|c|}{ Variabel } & $\begin{array}{c}\text { Conbach } \\
\text { Alpa }\end{array}$ & $\begin{array}{c}\text { Rule of } \\
\text { Thumb }\end{array}$ & Keterangan \\
\hline Kepercayaan= $k p c$ & 0,757 & 0,60 & Reliabel \\
\hline Persepsi Resiko=rsk & 0,765 & 0,60 & Reliabel \\
\hline Persepsi Manfaat=mnf & 0,805 & 0,60 & Reliabel \\
\hline Persepsi Harga=hrg & 0,772 & 0,60 & Reliabel \\
\hline Minat Beli=mntbl & 0,805 & 0,60 & Reliabel \\
\hline
\end{tabular}

Dari tabel di atas dapat dijelaskan bahwa kelima instrument memiliki nilai Cronbach Alpha lebih besar dari nilai Rule of Thumb. Dengan hasil tersebut sesuai dengan kriteria pengujian reliabilitas suatu instrumen yang baik yaitu koefisien alpha diantara 0,6 sampai 0,8 dianggap reliabilitas yang dapat diterima dan dinyatakan reliabel.

3. Hasil Uji Regresi Linier Berganda Hasil Analisis Linier Berganda

\begin{tabular}{|l|r|r|}
\hline \multicolumn{1}{|c|}{ Model } & \multicolumn{1}{c|}{ B } & \multicolumn{1}{c|}{ Sig. } \\
\hline (constanta) & 3.213 & .107 \\
\hline Kepercayaan & .062 & .206 \\
\hline Persepsi Resiko & -.057 & .234 \\
\hline Persepsi Manfaat & .456 & .000 \\
\hline Persepsi Harga & .111 & .066 \\
\hline
\end{tabular}

$\mathrm{Y}=3.231+0,062 \mathrm{X} 1-0,057 \mathrm{X} 2+$ $0,456 \mathrm{X} 3+0,111 \mathrm{X} 4$

Dari persamaan tersebut dapat diuraikan sebagai berikut:

a. Konstanta sebesar menyatakan jika tidak ada faktor yang mempengaruhi Minat beli pada situs jual beli online (Kepercayaan, Persepsi Resiko, Persepsi Manfaat, dan Persepsi Harga), maka Minat Beli pada Situs Jual Beli Online adalah sebesar 3.231 .

b. Koefisien regresi sebesar 0,062 menyatakan bahwa setiap penambahan 1 tingkat Kepercayaan, maka akan menaikan Minat Beli Pada Situs Jual Beli Online sebesar 0,062 .

c. Koefisien regresi sebesar $-0,057$ menyatakan bahwa setiap pengurangan 1 tingkat Persepsi Resiko, maka akan menurunkan Minat Beli Pada Situs Jual Beli Online sebesar -0,057. 
d. Koefisien regresi sebesar 0,456 menyatakan bahwa setiap penambahan 1 tingkat Persepsi Manfaat, maka akan menaikan Minat Beli Pada Situs Jual Beli Online sebesar 0,456.

e. Koefisien regresi sebesar 0,111 menyatakan bahwa setiap penambahan 1 tingkat Persepsi Harga, maka akan menaikan Minat Beli Pada Situs Jual Beli Online sebesar 0,111.

\section{Hasil Uji Parsial (Uji T)}

Rekapitulasi Pengaruh Faktor Kepercayaan, Persepsi Resiko, Persepsi Manfaat Dan Persepsi Harga Terhadap Minat Beli Pada Situs Jual Beli Online

\begin{tabular}{|l|c|l|l|l|}
\hline \multicolumn{1}{|c|}{ Minat Beli } & Sig. & & alpha & \multicolumn{1}{|c|}{ Hipotesis } \\
\hline Kepercayaan & 0,206 & $>$ & 0,05 & $\begin{array}{l}\text { Tidak berpengaruh } \\
\text { secara signifikan }\end{array}$ \\
\hline Persepsi Resiko & 0,234 & $>$ & 0,05 & $\begin{array}{l}\text { Tidak berpengaruh } \\
\text { secara signifikan }\end{array}$ \\
\hline Persepsi manfaat & 0,000 & $<$ & 0,05 & $\begin{array}{l}\text { Berpengaruh secara } \\
\text { signifikan }\end{array}$ \\
\hline Perseppsi Harga & 0,066 & $>$ & 0,05 & $\begin{array}{l}\text { Berpengaruh secara } \\
\text { signifikan }\end{array}$ \\
\hline
\end{tabular}

a. Kepercayaan

Hasil statistik uji $t$ untuk variabel Kepercayaan yang dipersepsikan diperoleh nilai $\mathrm{t}$ hitung sebesar 1,274 dengan nilai signifikansi sebesar 0,206 , nilai probabilitas alpha 0,05 lebih kecil dari pada 0,206 $(0,05<0,206)$, dan koefisien regresi mempunyai nilai positif sebesar 0,062; maka hasil pengujian ini tidak sesuai dan signifikan dengan hipotesis yang menyatakan bahwa "Kepercayaan berpengaruh terhadap minat beli konsumen online pada mahasiswa UAD kampus satu".

b. Persepsi Resiko

Hasil statistik uji t untuk variabel Persepsi Resiko yang dipersepsikan diperoleh nilai $\mathrm{t}$ hitung sebesar -1,198 dengan nilai signifikansi sebesar 0.234 , nilai probabilitas alpha 0,05 lebih kecil dari pada 0,234 (0,05<0,234), dan koefisien regresi mempunyai nilai negatif sebesar -0,057; maka hasil pengujian ini tidak sesuai dan signifikan dengan hipotesis yang menyatakan bahwa "Persepsi Resiko berpengaruh terhadap minat beli konsumen online pada mahasiswa UAD kampus satu".

c. Persepsi Manfaat

Hasil statistik uji t untuk variabel Kepercayaan yang dipersepsikan diperoleh nilai $\mathrm{t}$ hitung sebesar 4,519 dengan nilai signifikansi sebesar 0.000 , nilai probabilitas alpha 0,05 lebih besar dari pada $0,000(0,05>0,000)$, dan koefisien regresi mempunyai nilai positif sebesar 0,456 ; maka hasil pengujian ini sesuai dan signifikan dengan hipotesis yang menyatakan bahwa "Persepsi Manfaat berpengaruh terhadap minat beli konsumen online pada mahasiswa UAD kampus satu".

d. Persepsi Harga

Hasil statistik uji $\mathrm{t}$ untuk variabel Kepercayaan yang dipersepsikan diperoleh nilai $t$ hitung sebesar 1.861 dengan nilai signifikansi sebesar 0.066, nilai probabilitas alpha 0,05 lebih kecil dari pada 0,066 (0,05<0,066), dan koefisien regresi mempunyai nilai positif sebesar 0,111; maka hasil pengujian ini tidak sesuai dan signifikan dengan hipotesis yang menyatakan bahwa "Persepsi Harga berpengaruh terhadap minat beli konsumen online pada mahasiswa UAD kampus satu".

e. Hasil Uji Simultan (Uji F)

Uji Koefisien Regresi Serentak (Uji F) ANOVA

\begin{tabular}{|c|c|c|}
\hline Model & F & Sig. \\
\hline Regression & 16.697 & .000 \\
\hline
\end{tabular}

Dari hasil pengujian diperoleh nilai $\mathrm{F}$ hitung sebesar 16.697 dengan signifikansi sebesar 0,000 . Oleh karena nilai signifikansi lebih kecil dari 0,05 $(0,000<0,05)$ dan koefisien korelasi bernilai positif, maka hasil pengujian ini sesuai dan signifikan dengan hipotesis yang menyatakan bahwa 
"Ada pengaruh Kepercayaan, Persepsi Resiko, Persepsi Manfaat, dan Persepsi Harga, berpengaruh terhadap minat beli konsumen online pada mahasiswa UAD kampus satu secara bersamasama".

f. Hasil Uji Koefisien Determinasi

Koefisien Determinasi $\left(\mathrm{R}^{2}\right)$ dan Korelasi Komulatif (R)

\begin{tabular}{|c|c|}
\hline Model & R Square \\
\hline 1 & .413 \\
\hline
\end{tabular}

Dari hasil perhitungan dengan bantuan SPSS versi 16.0 menunjukan koefisien determinasi berganda yang telah disesuaikan (R2)/adjusted $\mathrm{R}$ Square yaitu sebesar 0,413 (maksud disesuaikan untuk derajat kebebasan (df) yang berkaitan dengan jumlah kuadrat yang ada). Hal ini bahwa 41,3\% dari Minat Beli pada situs jual beli online (Y) pada Mahasiswa Universitas Ahmad Dahlan Kampus Satu dapat dijelaskan oleh variabel X1 (Kepercayaan), X2 (Persepsi Resiko), X3 (Persepsi Manfaat), X4 (Persepsi Harga). Sedangkan 58,7\% dari kondisi variabel terikat diterangkan oleh variabel bebas lain yang tidak diamati oleh peneliti

\section{KESIMPULAN DAN SARAN}

\section{Kesimpulan}

1. Kepercayaan berpengaruh tidak signifikan pada minat beli konsumen pada situs jual-beli online, hal ini dibuktikan dengan nilai signifikansi lebih besar dari nilai probabilitas alpha $0,05 \quad(0,206>0,05)$, dan koefisien regresi mempunyai nilai positif sebesar 0,062 .

2. Persepsi Resiko berpengaruh tidak signifikan pada minat beli konsumen pada situs jual-beli online, hal ini dibuktikan dengan nilai signifikansi lebih besar dari nilai probabilitas alpha $0,05(0,234>0,05)$, dan koefisien regresi mempunyai nilai negatif sebesar $-0,057$.

3. Persepsi manfaat berpengaruh positif pada minat beli konsumen pada situs jual-beli online, hal ini dibuktikan dengan nilai signifikansi lebih kecil dari nilai probabilitas alpha 0,05 $(0,000<0,05)$, dan koefisien regresi mempunyai nilai positif sebesar 0,456 .

4. Persepsi Harga berpengaruh tidak signifikan pada minat beli konsumen pada situs jual-beli online, hal ini dibuktikan dengan nilai signifikansi lebih besar dari 0,05 (0,066>0,05), dan koefisien regresi mempunyai nilai positif sebesar 0,111 .

5. Kepercayaan, Persepsi Resiko, Persepsi Manfaat dan Persepsi Harga bersama-sama berpengaruh terhadap minat beli konsumen pada situs jualbeli online, hal ini dibuktikan dengan nilai signifikansi lebih kecil dari nilai probabilitas alpha $0,05(0,000<0,05)$. Hasil uji R2 pada penelitian ini diperoleh nilai $\mathrm{R} 2$ sebesar 0,413 .

\section{Saran}

1. Peneliti selanjutnya dapat mengembangkan penelitian ini dengan meneliti faktor lain yang dapat mempengaruhi Minat Beli, misalnya: Peneliti selanjutnya dapat memperbanyak jumlah responden yang diteliti, menggunakan metode pengambilan data secara online sehingga responden diperoleh akan lebih tepat dan lebih objektif dalam membeikan jawaban atas pertanyaanpertanyaan yang ada dalam kuesioner, serta peneliti selanjutnya juga menambahkan variabel-variabel lain seperti Persepsi Keamanan, Persepsi Privasi, Persepsi Kualitas produk dan Persepsi Kemudahan.

2. Dari kesimpulan di atas, hal yang perlu diperhatikan oleh masyarakat umum 
atau pihak penyedia situs layanan jual beli online yaitu: Penyedia layanan situs jual-beli online disarankan dapat lebih meningkatkan kemudahan bagi konsumen dalam hal mempercepat proses transaksi, dapat menemukan barang yang dicari dengan mudah, dapat memberikan keuntungan kepada konsumen ketika bertansaksi secara online. Sebab berdasarkan penelitian yang dilakukan pada Mahasiswa Universitas Ahmad Dahlan Kampus Satu yang mempengaruhi minat beli secara signifikan pada situs jual beli pada situs jual beli online adalah faktor Persepsi Manfaat dan Persepsi Harga.Penyedia layanan situs jual-beli online sebaiknya juga memperhatikan faktor kepercayaan serta faktor persepsi resiko konsumen. Sebab meskipun dalam penelitian ini faktor kepercayaan dan faktor persepsi resiko tidak berpengaruh secara parsial, namun secara bersamasama atau keseluruhan faktor kepercayaan, persepsi resiko, persepsi manfaat, dan persepsi harga memiliki pengaruh yang signifikan terhadap minat beli konsumen pada situs jual-beli online

\section{DAFTAR PUSTAKA}

Adhilla, Fitroh, dkk. (2013). Modul Praktikum Satistik 2. Yogyakarta: Universitas Ahmad Dahlan.

Algifari. (2013). Statistika Deskriptif Plus Untuk Ekonomi Dan Bisnis. Yogyakarta: UPP STIM YKPN.

APJII. (2015). Profil penggunaan internet 2014. Jakarta: APJII.

Kotler, Philip dan Kevin Lane Keller. (2008). Manajemen Pemasaran. Edisi 12 Jilid 2. Jakarta: Indeks.

Mowen, John C, dan Michael Minor. (2001). Perilaku Konsumen. Edisi 5 Jilid 1. Jakarta: Erlangga.
Nusarika, Luh Alviolita Kusuma, dan Ni Made Purnami. (2015). Pengaruh Persepsi Harga, Kepercayaan, dan Orientasi Belanja Terhadap Niat Beli Secara Online (Studi pada Produk Fashion Online di Kota Denpasar). E-Jurnal Manajemen Unud, Vol. 4, No. 8, 2015: 2380-2406 ISSN : 2302-8912.

Oktavianingrum, dkk. (2015). Effect Of Risk Perception, Trust, and Psycology Of Youth Clothing Online Purchase Decision Among University Students Pandanaran Semarang. Artikel Terpublikasi.

Peter, J. Paul dan Jerry C. Olson. (2014). Perilaku Konsumen Dan Strategi Pemasaran. Jakarta: Salemba Empat.

Rachman, Febian., Riskon Ginting dan Hafniza Amir. (2014). Pengaruh Stimulus Produk, Harga, Dan Promosi Trhadap Minat Beli Produk Baru Jenis Fashion Yang Dipasarkan Di Forum Jual Beli Kaskus. Epigram. Vol. 11 No. 2 Oktober 2014:173-182.

Rianto, Imam Teguh. (2003). Analisis Faktor Penelitian dan Pengembangan Manajemen. Yogyakarta: Universitas Ahmad Dahlan.

Sangadji, Etta Mamang dan Sopiah. (2013). Perilaku Konsumen, Pendekatan Praktis. Yogyakarta: Andi.

Sugiyono. (2008). Metode Penelitian Bisnis. Bandung: Alfabeta.

Sugiyono. (2010). Metode Penelitian Bisnis. Bandung: Alfabeta.

Swastha, Basu dan Irawan. (2008). Manajemen Pemasaran Modern. Yogyakarta: Liberty. 
Trisnawati, Ella, Agus Suroso, dan Untung

Kumorohadi. (2012). Analisis

Faktor-Faktor Kunci Dari Niat

Pembelian Kembali Secara Online

(Study Kasus Pada Konsumen

Fesh Shop). Jurnal Bisnis dan

Ekonomi (JBE), September 2012,

Hal. $126-141$ Vol. 19, No. 2 ISSN:

$1412-3126$

Yusnidar, dkk. (2014). Pengaruh

Kepercayaan dan Persepsi Resiko

Terhadap Minat Beli dan Keputusan

Pembelian Produk Fashion Secara

Online di Kota Pekanbaru. Jurnal

Sosial Ekonomi Pembangunan,

Tahun IV No.12, Juli 2014 : 311-

329. 